\title{
Lowered Virulence to Rice Plants and Decreased Biosynthesis of Gibberellins in Mutants of Gibberella fujikuroi Selected with Pefurazoate
}

\author{
Mitsuaki Takenaka, Keisuke Hayashi, Tohru Ogawa,* \\ Shuichiro KImURA and Toshinobu TANAKA \\ Ube Research Laboratory, Ube Industries Ltd., \\ *Ube Scientific Analysis Laboratory, Inc., Kogushi, Ube 755, Japan
}

(Received January 13, 1992; Accepted May 8, 1992)

\begin{abstract}
Mutants of Gibberella fujikuroi were obtained by selection from a large number of conidia of a wild type field isolate of the fungus on agar plates containing lethal concentration of a sterol demethylation inhibitor, pefurazoate. The mutants isolated from the colonies grown on the plates had higher minimal growth-inhibitory concentrations of pefurazoate and the $\mathrm{EC}_{95}$ values were higher than that for the mother isolate but only a small increase was observed in the $\mathrm{EC}_{50}$ values. Though the slope of the dosage-response curve was changed in the mutants, the mechanism of action of the fungicide in a mutant proved to be its inhibition of sterol $14 \alpha$-demethylation as shown by an experiment on inhibition of ergosterol biosynthesis using ${ }^{14} \mathrm{C}$-acetate. Gibberellin production in the mutants in liquid culture was tested by bioassay of gibberellins and assay of gibberellin $A_{3}$ using HPLC. Mutants were also tested for their virulence to rice plants. Decreased virulence due to decreased production of gibberellins was observed in the mutants. A mutational change in a site related to $14 \alpha-$ demethylation in ergosterol biosynthesis and to kaurene oxidation in gibberellin biosynthesis in common is discussed.
\end{abstract}

\section{INTRODUCTION}

Sterol demethylation inhibitors (DMIs) such as triflumizole and pefurazoate have been developed and used as seed fungicides for the last several years in Japan to control Bakanae disease of rice caused by Gibberella fujikuroi (Fusarium moniliforme). Since fungal resistance to modern selective fungicides is sometimes a problem in the field, monitoring of sensitivity to the above-mentioned fungicides has already been conducted. Hamamura et $a l .{ }^{1)}$ observed a wide range of sensitivity to triflumizole among field isolates of the fungus. However less sensitive isolates were less virulent to host plants presumably due to low production of gibberellins. Wada and his coworkers $^{2)}$ also surveyed sensitivities of field isolates of the fungus to triflumizole and to pefurazoate, fungal gibberellin production and their virulence to rice plants. They observed that the range of distribution of sensitivity to the fungicides was seemingly narrower and the relationship between sensitivity to the fungicides and virulence to rice plants was roughly similar but a little more variable as compared with the observation by Hamamura et al.

The relation between $14 \alpha$-demethylation in fungal sterol biosynthesis and kaurene oxidation in gibberellin biosynthesis in higher plants has already been reported and discussed by Sisler \& Ragsdale. ${ }^{3)}$ They pointed out the similarity of enzymes involved in the two processes and their sensitivity to similar inhibitors.

The relation between inhibition of fungal biosynthesis of gibberellins and fungal growth inhibition was studied by Coolbaugh et al.,") 
using three DMI fungicides and two plant growth regulators which inhibit kaurene oxidation. The order of effectiveness of the five test compounds as inhibitors of fungal biosynthesis of gibberellins was similar to that as inhibitors of fungal growth. Since the order of effectiveness as inhibitor of gibberellin biosynthesis in higher plants was different from that in the fungus, they suggested that the kaurene oxidation systems from the two sources have somewhat different molecular characteristics.

The present experiments were conducted to elucidate how the mutational change in sensitivity to a DMI fungicide affect the fungal gibberellin production and virulence to rice plants, using laboratory-derived mutants of G. fujikuroi selected with pefurazoate.

\section{MATERIALS AND METHODS}

\section{Test Fungus and Fungicide}

A wild type (W) field isolate of G. fujikuroi coded as 167-1 was kindly supplied in 1987 by Shimane Prefectural Agricultural Experiment Station. It was originally obtained by single spore isolation from a rice field where no DMI fungicides had been used in rice cultivation. The isolate was subcultured on potato dextrose agar (PDA) medium and stored in the laboratory. Technical grade pefurazoate (Healthied $\left.{ }^{\circledR}\right)$, pent-4-enyl $N$ furfuryl - $N$-imidazol - 1 - ylcarbonyl-DL-homoalaninate, having 95\% purity was used for most tests. Enantiomers of the fungicide ${ }^{5}$ ) were also used in some of the present experiments.

\section{Selection of the Conidia with the Fungicide}

Pefurazoate was dissolved in acetone and added to molten PDA medium which was then dispensed into Petri dishes of $9 \mathrm{~cm}$ diameter and allowed to solidify. One hundred microliters of a suspension of the conidia collected from fungal mats on PDA medium was added and spread uniformly on the surface of the medium in each plate. The medium contained $10^{6} \mu \mathrm{g} / \mathrm{ml}$ of the fungicide. Several colonies per $10^{8}$ conidia grew and each of the colonies was transferred to fungicide-free PDA 10 days after inoculation. Single spore isolation was then made from the subcultures of the in- sensitive colonies. Nine insensitive mutants thus obtained from the field isolate were used for the present experiments.

\section{Sensitivity Evaluation}

Measurements of minimal inhibitory concentration (MIC) of the fungicide to fungal growth at $28^{\circ} \mathrm{C}$ and of growth rates in the presence of the fungicide were made three days. after inoculation of fungicide-amended PDA medium with $1 \mathrm{~mm}$ square segments from mycelial mats. This method is similar to that in the relevant report ${ }^{5)}$ except for the modification of incubation period from four days to three days.

\section{Effect of Enantiomers of Pefurazoate on Ergosterol Biosynthesis in a Mutant}

Effect of the enantiomers of pefurazoate on biosynthesis of ergosterol and related sterols from $1-{ }^{14} \mathrm{C}$-labeled acetate in one of the mutants, M7, was tested by the method reported elsewhere. ${ }^{5)}$

\section{Evaluation of Virulence}

The mutants obtained were tested for virulence to a dwarf rice cultivar, Wai-Tou C. Seeds of the test cultivar were inoculated with the mother field isolate and its mutants by soaking the seeds in suspension of the fungal conidia $\left(2 \times 10^{6}\right.$ spores $\left./ \mathrm{ml}\right)$ for $24 \mathrm{hr}$ at $25^{\circ} \mathrm{C}$ followed by sowing on soil in plastic containers. After 20 days under greenhouse conditions, 60 plants per container at the 3- to 4-leaf stage were evaluated for leaf elongation as compared with the uninoculated control plants. Rate of disease incidence was also calculated from the number of diseased plants which were clearly elongated and appeared abnormal as compared with the control plants. Three replications were used for these tests for virulence.

\section{Examination of Fungal Production of Gibberellins}

To examine the fungal production of gibberellins, $2 \times 10^{6}$ conidia of the mother field isolate and of its mutants were cultured in $100 \mathrm{ml}$ of Richard's medium with shaking in the dark for 5 days at $28^{\circ} \mathrm{C}$. This liquid medium is said to be favorable for production of gibberellin $\mathrm{A}_{3}\left(\mathrm{GA}_{3}\right)$ without causing con- 
siderable production of fusaric acid and is often used in this kind of experiments. ${ }^{1,2)}$ Bioassay of gibberellins in the culture liquid of the mother isolate and its mutants was made using the dwarf rice cultivar Wai-Tou $\mathrm{C}$ as the test plant. ${ }^{6}$. The culture filtrate was adjusted to $\mathrm{pH} 3.0$ with $\mathrm{HCl}$ and extracted with ethyl acetate. Solvent was evaporated and the extract was dissolved again in acetonewater $(1: 1)$, adjusted to $\mathrm{pH} 7.0$ with $\mathrm{NaOH}$, and assayed for gibberellins. Amount of gibberellins was estimated as $\mathrm{GA}_{3}$ equivalent from a calibration curve obtained from the elongation effect on the rice seedlings produced by authentic $\mathrm{GA}_{3}$ purchased from Ishizu Pharmaceutical. The value by this bioassay includes various gibberellins and may be affected by stunting effect of fusaric acid in the culture extracts and will be discussed later. The above extract was also used for evaluation of $\mathrm{GA}_{3}$ and fusaric acid by HPLC. It was conducted with Shimadzu LC-6A apparatus equipped with a loop type sample injector (Rheodyne, USA), TSK-gel ODS-80TM column $(4.6 \mathrm{~mm} \phi \times 250 \mathrm{~mm}$, Tosoh Co.), Shimadzu SPD-6A spectrometer for detection and Chromatopak C-R4AX integrator (Shimadzu) for data process. Elution was made with a mixture of $0.1 \mathrm{~m}$ phosphate buffer $(\mathrm{pH} 2.1)$ and acetonitrile $(4: 1)$ containing $0.8 \mathrm{~mm}$ sodium 1-octanesulfonate as a mobile phase at a flow rate of $1.0 \mathrm{ml} / \mathrm{min}$ at $40^{\circ} \mathrm{C}$. For quantification of fusaric acid and $\mathrm{GA}_{3}$, salicylic acid was used as an internal standard and they, were monitored by UV absorption at $210 \mathrm{~nm}$. Authentic standard of fusaric acid was purchased from Sigma.

\section{RESULTS}

1. Result of the Selection of the Mutants Less Sensitive to Pefurazoate

In the present experiment, frequency of emergence of pefurazoate-insensitive mutants was between $10^{-8}$ and $10^{-7}$. No difference was observed between the mutants obtained and the wild type mother field isolate with respect to appearance and growth rate in culture in the laboratory except pefurazoate sensitivity.

The sensitivity of the mutants to pefurazoate was shown by the effective concentration required for $50 \%$ response $\left(\mathrm{EC}_{50}\right)$, for $95 \%$
Table 1 Sensitivity to pefurazoate of a wildtype field isolate of Gibberella fujikuroi (W) and of its mutants (M1 to M7) selected with the fungicide.

\begin{tabular}{cccc}
\hline \multirow{2}{*}{$\begin{array}{c}\text { Test isolate } \\
\text { and mutants }\end{array}$} & \multicolumn{3}{c}{ Sensitivity $(\mu \mathrm{g} / \mathrm{ml})$} \\
\cline { 2 - 4 } & $\mathrm{EC}_{50}$ & $\mathrm{EC}_{95}$ & $\mathrm{MIC}$ \\
\hline (Field isolate) & & & \\
W & 0.19 & 2.1 & 2.5 \\
(Mutants) & & & \\
M1 & 0.25 & 7.6 & $>20$ \\
M2 & 0.22 & 5.7 & 20 \\
M3 & 0.36 & 7.8 & 20 \\
M4 & 0.22 & 3.2 & 10 \\
M5 & 0.22 & 6.7 & 20 \\
M6 & 0.27 & 5.4 & $>20$ \\
M7 & 0.25 & 7.3 & $>20$ \\
M8 & 0.32 & 7.6 & $>20$ \\
M9 & 0.26 & 8.9 & 20 \\
\hline
\end{tabular}

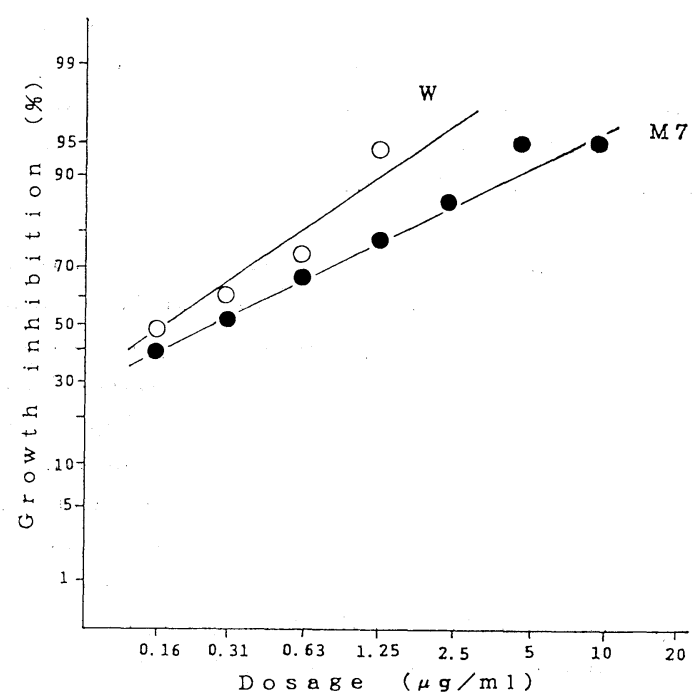

Fig. 1 Dosage-response (DR) curves to pefurazoate of a wild-type field isolate (W) of Gibberella fujikuroi and one of its mutants, M7, selected with the fungicide.

response $\left(\mathrm{EC}_{95}\right)$ and minimal inhibitory concentration (MIC) in comparison with those required to produce a similar response of the mother isolate: (Table 1). Considerable difference was found in MIC and $\mathrm{EC}_{95}$ between the mother isolate and its mutants but the difference in $\mathrm{EC}_{50}$ was less remarkable. It means the slope of dosage-response (DR) curve 
is gentle in the mutants as compared with that for the mother isolate. A DR curve for one of the mutants M7 and that of the mother isolate are shown in Fig. 1. All the other mutants showed DR curves close to that of M7 though that of a mutant M4 laid between M7 and the mother field isolate.

\section{Antifungal Mechanism of Pefurazoate in a Mutant}

Fungicidal mechanism of enantiomers of pefurazoate to one of the mutants was studied. The effects of the enantiomers on ergosterol biosynthesis are shown in Table 2.

Incorporation of radioactivity into ergosterol fraction from ${ }^{14} \mathrm{C}$-acetate was strongly inhibited by the $(S)-(-)$-isomer. Concomitant accumulation of 14-methylsterols, such as 24methylenedihydrolanosterol and obtusifoliol, was also observed showing the inhibition of $14 \alpha$-demethylation in ergosterol biosynthesis. The $(R)-(+)$-isomer also inhibited the ergosterol biosynthesis and caused accumulation of 14-methylsterols, but the effect was smaller than with the $(S)-(-)$-isomer.

\section{Evaluation of Fungal Gibberellin Production}

Four mutants, M1, M4, M6 and M7, were tested for gibberellin production. The results of evaluation of gibberellins and fusaric acid are shown as amount per $g$ dry weight of mycelia in Table 3 . The results of bioassays of gibberellins were thought to be affected by stunting effects of fusaric acid produced along with gibberellins as stated before. The stunting effect of fusaric acid on elongation by $\mathrm{GA}_{3}$ was, therefore, checked on the test dwarf rice plants. Higher concentration of fusaric acid really cancelled the elongation effect of $\mathrm{GA}_{3}$ especially at higher concentration of $\mathrm{GA}_{3}$. However, lower concentration of fusaric acid did not show the stunting effect in the presence of GAs but showed a slight amplifying effect on the elongation by $\mathrm{GA}_{3}$ at lower concentration of $\mathrm{GA}_{3}$. At the concentrations of $\mathrm{GA}_{3}$ (around $20 \mu \mathrm{g} / \mathrm{ml}$ or lower in test solution for application to test plants) and of fusaric acid (around $25 \mu \mathrm{g} / \mathrm{ml}$ or lower) used, the effect of fusaric acid on elongation of the test plants seemed negligible under the present test conditions. Thus, amounts of gibberellins evaluat-
Table 2 Percentages of incorporation of $1^{1-14} \mathrm{C}$ acetate into lipid fractions of the mutant M7 of Gibberella fujikuroi in the presence of isomers of pefurazoate.

\begin{tabular}{crrrr}
\hline \multirow{2}{*}{$\begin{array}{c}\text { Isomers } \\
\text { added }\end{array}$} & \multicolumn{3}{c}{ Sterols } & $\begin{array}{c}\text { Other } \\
\text { lipids }\end{array}$ \\
\cline { 2 - 4 } & 24-MDL & OF & ES & \\
\hline $\begin{array}{c}\text { Untreated } \\
\text { control }\end{array}$ & 0.7 & 1.0 & 11.2 & 87.1 \\
$(S)$-(-)-isomer & 8.2 & 8.7 & 1.4 & 83.1 \\
$(R)$-(+)-isomer & 5.0 & 4.2 & 4.6 & 86.2 \\
\hline
\end{tabular}

Concentration of isomers added: $0.24 \mu \mathrm{g} / \mathrm{ml}$.

Abbreviations of sterol names: 24-MDL, 24methylenedihydrolanosterol; OF, obtusifoliol; ES, ergosterol.

Table 3 Amounts of gibberellins evaluated by bioassay, and gibberellin $\mathrm{A}_{3}$ and fusaric acid evaluated by HPLC in extract of culture filtrate of Gibberella fujikuroi.

\begin{tabular}{ccccc}
\hline & Bioassay & & \multicolumn{2}{c}{ Assay by HPLC } \\
\cline { 2 - 3 } \cline { 5 - 6 } $\begin{array}{c}\text { Test isolate } \\
\text { and mutants }\end{array}$ & $\begin{array}{c}\text { Gibberellins } \\
\text { (mg GA } \\
\text { eq./g } \\
\text { dry wt. })\end{array}$ & & $\begin{array}{c}\text { Gibberellin } \\
\mathrm{A}_{3} \\
(\mathrm{mg} / \mathrm{g} \\
\text { dry wt. })\end{array}$ & $\begin{array}{c}\text { Fusaric } \\
\text { acid } \\
\text { (mg/g } \\
\text { dry wt. })\end{array}$ \\
\hline Field isolate W & 0.91 & & 1.40 & 0.72 \\
Mutant M1 & 0.03 & & 0.51 & 1.67 \\
M4 & 0.43 & & 0.82 & 1.61 \\
M6 & 0.14 & & 0.10 & 0.71 \\
M7 & 0.34 & & 0.12 & 1.13 \\
\hline
\end{tabular}

ed by bioassay and those of $\mathrm{GA}_{3}$ assayed by HPLC produced by the mutants were lower than those produced by the wild type mother field isolate.

$\mathrm{GA}_{3}$ production versus pefurazoate sensitivity as expressed in $\mathrm{EC}_{95}$ is shown in Fig. 2. $\mathrm{GA}_{3}$ production decreased with decrease in sensitivity to pefurazoate.

\section{Virulence of the Mutants on Rice Plants}

The above four mutants of the fungus were also tested for virulence to the host plants. Disease incidence and development of the symptom, i.e. elongation of the host plants, are shown versus sensitivity of the mutants to pefurazoate (Fig. 2) and versus $\mathrm{GA}_{3}$ production (Fig. 3). Lowered virulence in the mutants in comparison with their mother 


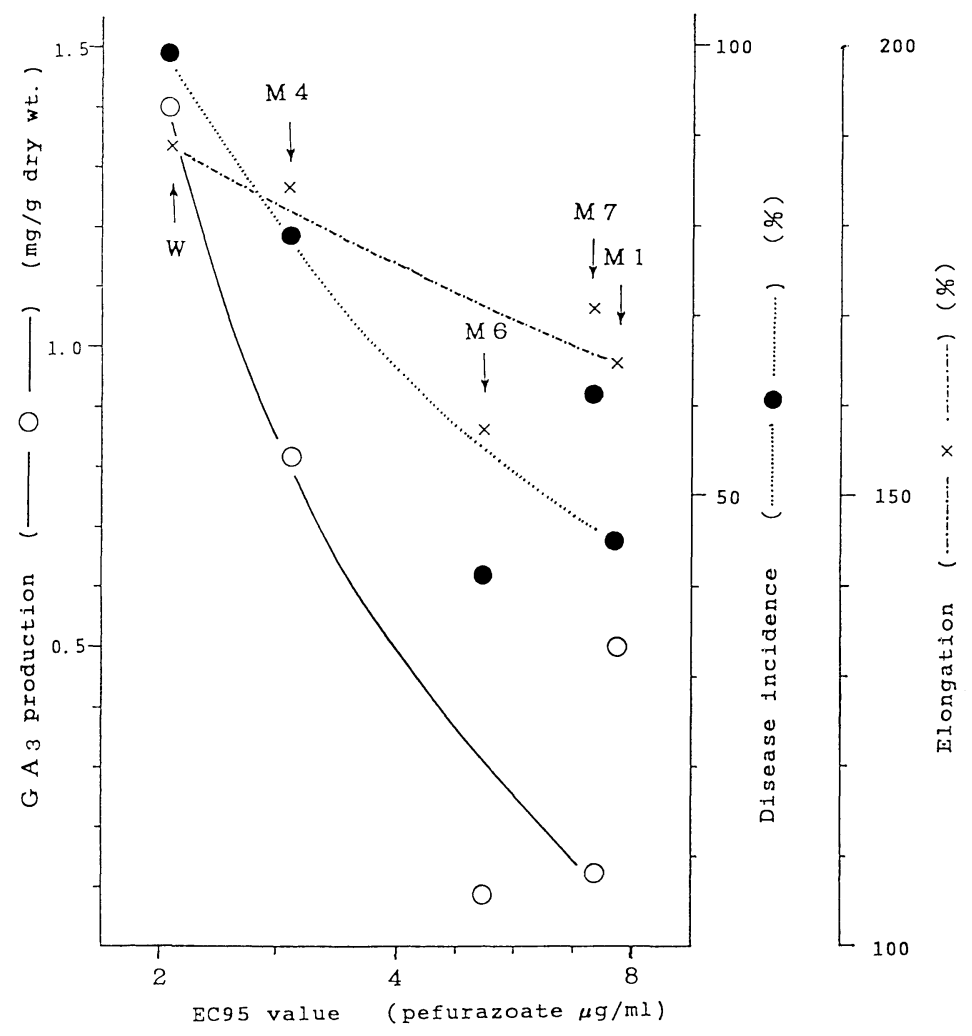

Fig. 2 Relationships to $\mathrm{EC}_{95}$ value of production of gibberellin $\mathrm{A}_{3}\left(\mathrm{GA}_{3}\right)$ in liquid culture and of virulence as expressed by disease incidence and by elongation of rice plants among a field isolate of G. fujikuroi and its mutants selected with pefurazoate.

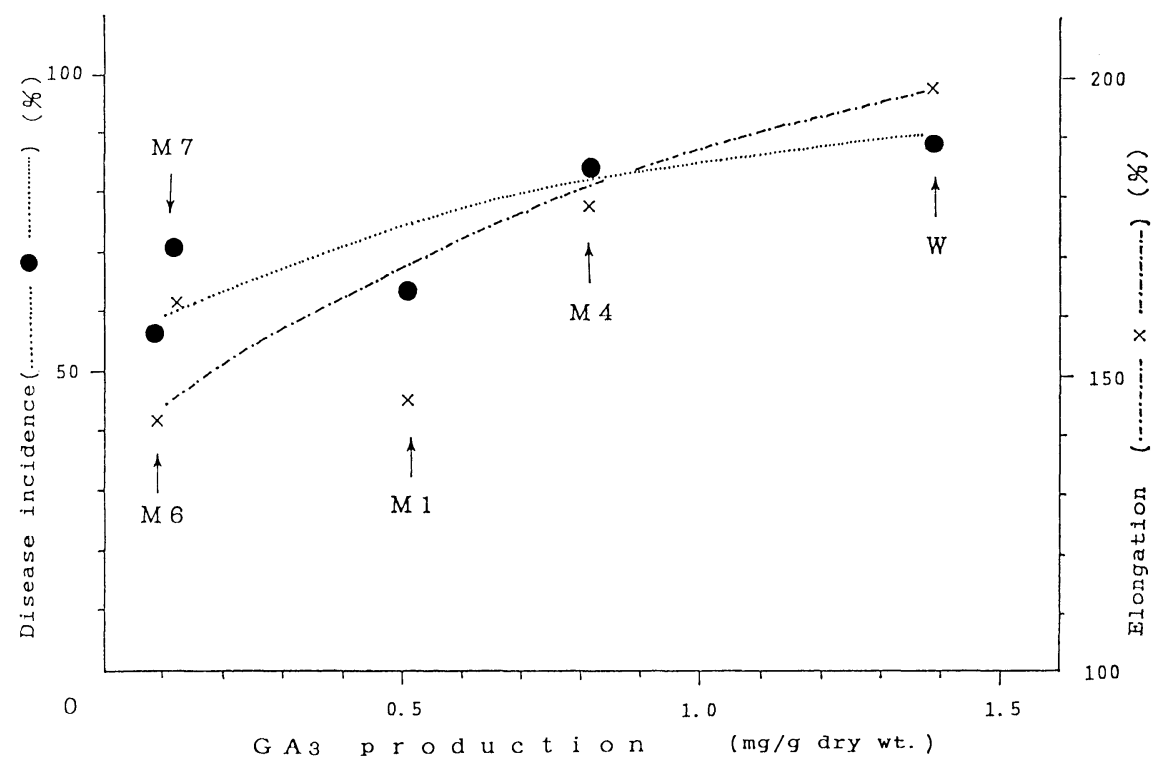

Fig. 3 Relationships of disease incidence and of elongation of rice to $\mathrm{GA}_{3}$ production among a field isolate of G. fujikuroi and its mutants selected with pefurazoate. 


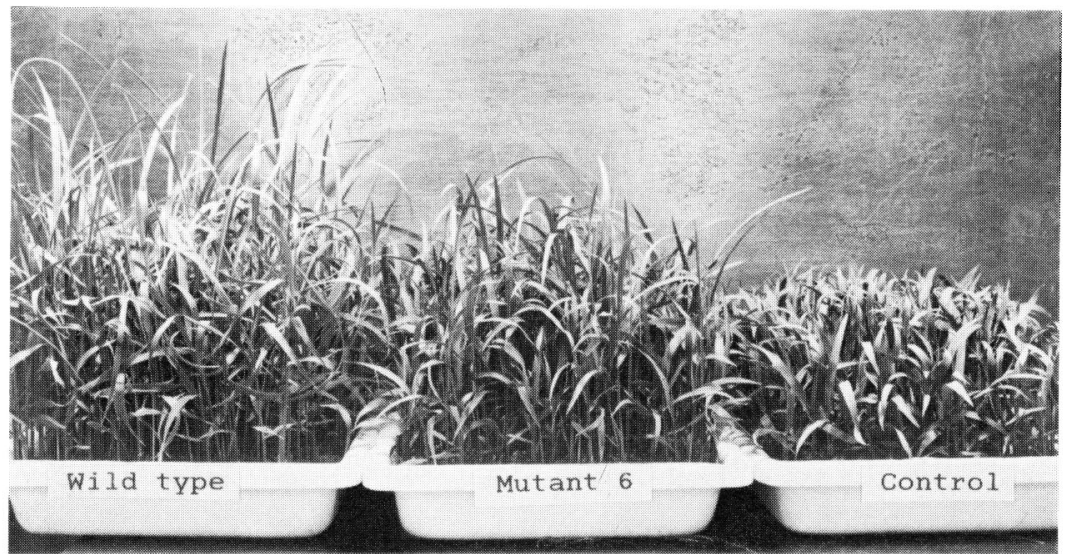

Fig. 4 Rice plants infected by a field isolate of G. fujikuroi (left) and by its mutant, M6, (middle) and uninoculated rice plants (right).

isolate seemed to be connected with decreased sensitivity to pefurazoate and with decreased production of $\mathrm{GA}_{3}$. A part of the experiment is also shown by a photograph (Fig. 4).

\section{DISCUSSION}

For the present investigation, mutants of the fungus produced by a single gene mutation are most desirable. Chemical or physical treatment followed by the selection or training of the fungus with increasing concentration of fungicides in each of several transfers are often used to obtain mutants insensitive to fungicides. By these methods multiple mutations were more likely than by the present method. The mutants obtained were believed to have resulted from naturally occurring spontaneous mutations and multiple mutation seemed unlikely in the present selection.

The mutants obtained by the selection had DR curves with different slopes in comparison with that of the mother isolate. Slope of the curve has often been discussed as an indication of mechanism of action of a group of fungicides. ${ }^{7)}$ Since a difference in the slope of the DR curve was shown between the mother isolate and its mutants, the fungicidal mechanism in mutants was examined. The results showed that the mechanism of action of pefurazoate was inhibition of $14 \alpha$-demethylation in ergosterol biosynthesis just as in the wild type fungus. ${ }^{5)}$ Since slope of DR curve shows the range of distribution of sensitivity among cells of the test fungus, a gentle slope of a DR curve and an increased $\mathrm{EC}_{95}$ value in mutants suggest that the site of action of pefurazoate or some factor(s) related to the site is modified in such a way that the range of distribution of the sensitivity among cells is widened in a less sensitive direction.

With respect to gibberellin production in the mutants obtained, the results presented in Fig. 2 shows that mutation to a lower sensitivity to the fungicide is associated with a decrease in gibberellin production. The point to be discussed here is the connection of the gene related to sensitivity to the DMI and to fungal production of gibberellins. As Sisler \& Ragsdale suggested, ${ }^{3)}$ the site of action of DMI fungicides, which is the $14 \alpha$-demethylation step mediated by a mixed function oxygenase (mfo) in fungal ergosterol biosynthesis, may be similar to the site of kaurene oxidation, which is a step of gibberellin biosynthesis involving an mfo. Thus, DMI fungicides, such as azole fungicides, often cause stunting effect on growth of higher plants. But there might be some difference between the DMI site in fungal cells and the site of kaurene oxidation in higher plants as elucidated by Takano and his coworkers ${ }^{8)}$ who reported the biological actions of optical isomers of another DMI fungicide, diniconazole. The $(R)-(-)$-isomer of this compound is the stronger fungicide, while the $(S)-(+)$-enantiomer shows stronger stunting effect on growth 


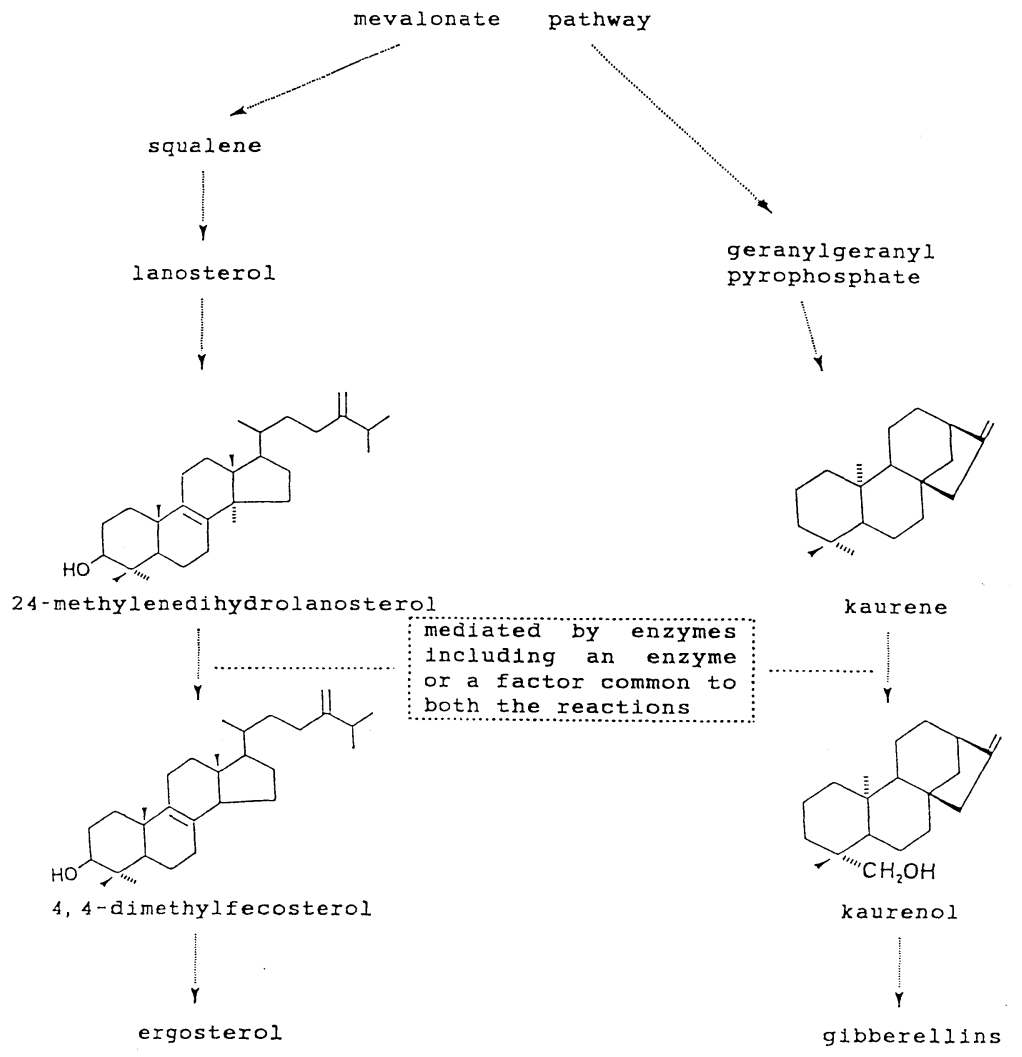

Fig. 5 Pathways of fungal biosyntheses of ergosterol and gibberellins in G. fujikuroi and the proposed sites where a mutational change affects the gibberellin biosynthesis and sensitivity to pefurazoate in ergosterol biosynthesis.

of cucumber plants. However, in studies of the effect of the same fungicide on gibberellin biosynthesis in G. fujikuroi, it was found that the fungicidal $(R)-(-)$-isomer is more potent also as an inhibitor of fungal gibberellin biosynthesis. ${ }^{9)}$ In the case of pefurazoate, the $(S)$-(-)-isomer is the fungicidal principle for the wild type fungus as well as for the mutants mentioned above, but its inhibition of fungal gibberellin biosynthesis was not tested in the present experiments and remains to be studied in the future.

The results on virulence and gibberellin production and on antifungal characteristics of pefurazoate shown by DR curves for the mother isolate and its fungicide insensitive mutants obtained in the present experiments may be plausibly explained as follows:

The mixed function oxigenase involved in $14 \alpha$-demethylation in ergosterol biosynthesis or a factor or an enzyme linked to this mfo is common to or at least closely related to that involved in kaurene oxidation in gibberellin biosynthesis in the fungal cells (Fig. 5). A single mutation of the gene coding for the enzyme or the factor caused a decrease in sensitivity to the fungicide and a concomitant reduction in kaurene oxidation followed by decreased production of gibberellins in the fungal cells.

\section{ACKNOWLEDGMENTS}

Authors are indebted to Dr. Y. Uesugi of Ube Research Laboratory, Ube Industries, Ltd., for his valuable suggestions and discussion on the experiments and to Dr. H. D. Sisler of University of Maryland for discussion and critical reading of the manuscript. They are also thankful to Ms. N. Suemura and Mr. M. Ikeda of Ube Scientific Analysis Laboratory, Inc., for their technical assistance in analysis. 


\section{REFERENCES}

1) H. Hamamura, M. Kawahara \& S. Shimoda: Ann. Phytopathol. Soc. Jpn. 55, 275 (1989)

2) T. Wada, S. Kuzuma \& M. Takenaka: Ann. Phytopathol. Soc. Jpn. 56, 449 (1990)

3) H. D. Sisler \& N. N. Ragsdale: Neth. J. Plant Pathol. 83 (Suppl. 1), 81 (1977)

4) R. C. Coolbaugh, D. R. Heil \& C. A. West: Plant Physiol. 69, 712 (1982)

5) M. Takenaka, S. Kimura, T. Tanaka \& T. Wada: J. Pesticide Sci. 17, 205 (1992)

6) H. Yamane \& N. Takahashi: "Bioassay of Physiologically Active Substances," ed. by N. Ikekawa, S. Marumo \& M. Hoshi, Koudansha, Tokyo, pp. 105-116, 1984

7) J. G. Horsfall: "Principles of Fungicidal Action," Chronica Botanica Co., Waltham, Mass., U.S.A., p. 21, 1956

8) H. Takano, Y. Oguri \& T. Kato: J. Pesticide Sci. 11, 373 (1986)

9) H. Takano, S. Inoue, H. Oshio, K. Kobayashi \& A. Ogoshi: Ann. Phytopathol. Soc. Jpn. 56, 409 (1990)

\section{要約}

\section{Pefurazoate で選抜したイネばか苗病菌変異株 におけるイネへの病原力低下とジベレリン生合 成の減少}

竹中允章，林 啓介，小川 徹 木村修一郎，田中敏房

野生型イネばか苗病菌の分生胞子多数を pefurazoate 含有寒天培地上に接種して，生育する同剤低感受性変異 菌株を分離した，変異菌株は野生型母株に比し，最低生 育阻止濃度 (MIC) や 95\% 有効濃度 (EC95) はかなり高 いが，50\% 有効濃度 $\left(\mathrm{EC}_{50}\right)$ では大きな差はなかった。 変異菌株では薬量一反応曲線の勾配が緩やかとなっては いたが， ${ }^{14} \mathrm{C}$-標識酶酸からの菌体脂質生合成への同郕の 影響を調べた結果では，作用機構はステロール 14 脱メチル阻害であった，変異菌株の液体培養でのジベレ リン生産を生物定量および HPLCによる定量を行な い, 一方, 変異菌株のイネに対する病原力試験を行なっ た結果，変異菌株においてはジベレリン生産の減少と病 原力の低下とが観察され，同菌のステロール生合成系の $14 \alpha$ 一位脱メチル過程とジベレリン生合成の一過程であ るカウレン酸化に共通に関与する酲素または因子に変異 を生したものと推察された。 